\title{
Article
}

\section{Tapering, tree rings and biomass production of Pinus roxburghii (Sarg.): A dendrochronological study}

\author{
Hari Prasad Pandey ${ }^{1, *}$ and Narayan Prasad Pokhrel ${ }^{2}$ \\ 1 Planning Officer, Ministry of Forests and Environment, Nepal. Email: pandeyhp123@gmail.com \\ 2 Scientific Officer, Ministry of Forests and Environment, Nepal. Email: narayan.botany123@gmail.com \\ * Correspondence:Corresponding author: pandeyhp123@gmail.com
}

Received: date; Accepted: date; Published: date

\begin{abstract}
Distinguishable annual growth rings produce in Pinus roxburghii are an asset to find out the age of individual tree. This paper aimed to determine the age of $P$. roxburghii through coring samples and test the relationship with forest production. The biomass estimated, girths measured at two different sections and heights measured which allowed to determine the rate of tapering of the stand. The regression analysis was performed to test the relationship between various variables. The mean age of the P. roxburghii stand was found to be 23.97 ( 24 years). The result showed the significant $(\mathrm{p}<0.05)$ positive correlation coefficient has been seen between age with girth at breast height, biomass, volume and carbon stock. However, no significant $(p>0.05)$ correlation $(r=0.08)$ was found between age and height of the stand. In contrast, a correlation between diameter at breast height $(\mathrm{DBH})$ was significant $(\mathrm{p}<0.05)$ and positive with volume, biomass, but no significant $(\mathrm{p}>0.05)$ correlation $(r=0.14)$ found between DBH and height of the stand. However, height has a significant $(p<0.05)$ positive correlation with biomass. The mean biomass was $375 \mathrm{~kg}$ and mean annual increment (MAI) was $15 \mathrm{~kg}$ per tree. Rate of tapering of the studied stand predicted to be $3 \mathrm{~cm}$ diameter decreased with trunk height running at $100 \mathrm{~cm}$ from base to upward of $P$. roxburghii stand and vice versa. Result suggests that height-age relation is very weak whereas age, DBH, biomass and carbon has a significant correlation signifies that time-based forests' production and potential production estimation can be obtained in a relatively accurate way by utilizing the age of stand. The time-based forest production analysis is pioneer work in Nepal. The study affirms the tree ring count in $P$. roxburghii would be a credible and accurate method to determine the age of standing trees.
\end{abstract}

Keywords: age; coring sample; forest productivity; Nepal; P. roxburghii; stand structure

\section{Introduction}

The Pinus roxburghii (Sarg.) belongs to the family Pinaceae, having three needled leaves, with long needles forming spherical pompom-like cluster at the end of the branches, especially in young trees [1]. The distribution of this species ranges from Bhutan, Myanmar, Sikkim, Tibet from the east to Nepal, India, Pakistan and Afghanistan on the west along the Hindu-Kush Himalayas foothills. In Nepal, its distribution ranges from $450 \mathrm{~m}$ to $2700 \mathrm{~m}$, mostly in south-facing dry areas [1]. The species form ecoregions in Nepal out of 12 ecoregions in the country $[2,3]$ and a major forest type in subtropical regions in Nepal [4]. After the energy crisis in Nepal in the 1970s due to mayhem of the Theory of Himalayas Environmental Degradation [5], the plantation work started and P. roxburghii became the most widely planted species during the 1980s and subsequent decades in Nepal [1]. As a result, a recent national forest assessment report highlighted some remarkable concerning $P$. roxburghii on the top of these past plantation and protection exercises. Despite constituting the diverse physiographic and climatic variation of the country [4], the species covers $8.45 \%$ of the total forested area of Nepal, 3.8 number of trees per hectares which constitutes $11.62 \mathrm{~m}^{3} \mathrm{ha}^{-1}$ stem volume. This 
figure is the third highest amount among all trees species (430), and having $12 \%$ frequency in all 2544 sample plots measured by the Department of Forest Research and Survey in Nepal [3].

The $P$. roxburghii produces a useful construction timber. In former times, $P$. roxburghii was the main species used for house-building in Kathmandu [1], and other major cities and countryside of Nepal. Nowadays, Shorea robusta tends to replace P. roxburghii in major cities but is still an important and prime source of wood for building construction in the hilly area of Nepal. The species has a calorific value of about $21,200 \mathrm{~kJ} / \mathrm{kg}$ as identified by Hawkins (1982) [1] and is widely used as fuelwood in Nepal. Recently, resin extracted from P. roxburghii has a growing market and has high economic returns to many forest users groups and for government revenue. For this reason, the government of Nepal brought and enforced a resin collection and management guideline for the sustainability of production and forests in 2008 [6]. These benefits only could be gained when the size or age of the tree determines that only stands more than $30 \mathrm{~cm}$ in diameter are allowed for resin tapping. The method for age determination would be coring. The coring is one of the established techniques that readily facilitates determination of age of standing trees or stands without significant tree damage for their future growth. Also, radial growth and wood density are important traits in assessing wood quality [7] that could be obtained from coring samples. The coring sample allows determining wood production history, wood quality and growth components in addition to many other aspects of the environment [8].

Several studies are employing differing methodologies to determine the age of standing trees and subsequent interrelationships. Some of these are ring count by destructive sampling techniques [9], coring by Pressler's borer [10, 11], and using radiometric scanner [12] or Tomography [13, 14]. If the forest is dominated by Pinus, the approximate age of the stands can be found by counting the whorls of branches [1]. But this technique is not scientific because pure Pinus stands in most case selfprune their branches which hinders the accurate counting of the whorls [15]. However, the destructive techniques of radiometric scanning or Tomography are, of course, the more accurate than the conventional whorls counting methods. But these tools and techniques are relatively time, effort, technology or resource demanding [8].

Measuring the size (diameter and height) would give a rough estimate to tree age but could not provide a relevant information on investigation on tree health issues [12], the rotation and productivity of the forest stand [16]. Despite having several high-tech infrared and radio wave-based tools and techniques in place to identify the age and quality assurance of wood in trees using software and a flat-bed scanner [17], the limitation on tools and techniques in Nepal due to limited coverage of many types of research in many areas and ecological data management [18]. In such instances, coring would be an efficient means of determining the age of the forest stands.

Despite $P$. roxburghii having a high rank on (5th rank, $5.05 \%$ by species among all trees species of Nepal) above ground biomass density $(9.90 \mathrm{t} / \mathrm{ha})[3,19]$ and have multiple benefits and readily available in Middle Mountains of the country, the study on age determination, age-based biomass production and potential carbon enhancement of this species is very limited. This is also spelt out by Gaire et al. (2013) and explore that the studies limited to 22 districts out of 77, mostly for Abies species from High Mountain and Himalayas regions of Nepal [20]. In this regards, tree rings counting could be the best options for available resources and techniques for ascertaining any information in annual ring forming species $[8,12]$ like P. roxburghii. Also, Gaire et al. (2013) suggested the future research potential of application of tree rings in wider aspects of dendroecology including biomass and carbon enhancement in the forests [20]. In this context, this study used a Pressler's borer sampler to extract the core sample by coring at diameter at breast height (DBH) of P. roxburghii to determine the age and explore the relationship of age with other variables including DBH, total height, volume, biomass and carbon in the Mid-hills of Nepal. The result gives insight on the age-based growth and production of $P$. roxburghii, and would be a reference for sustainable management of P. roxburghii forests across the regions.

\section{Materials and Methods}

\subsection{Study Area}


The study was conducted in Gorkha district, Mid-hills of Nepal. The Gorkha district extends between $27^{\circ} 15^{\prime}-28^{\circ} 45^{\prime} \mathrm{N}$ latitude and $84^{\circ} 27^{\prime}-84^{\circ} 58^{\prime} \mathrm{E}$ longitude, in the middle hills and high mountains of the Gandaki Province of Nepal. The district covers an area of $3614.70 \mathrm{~km}^{2}$, bounded by Tibet to the north, Dhading district to the east, Manang and Lamjung districts to the west, and Tanahun and Chitwan districts to the south, with an elevation range from $228 \mathrm{~m}$ asl at the bank of Trisuli river to $8,163 \mathrm{~m}$ asl at the top of Mount Manaslu [21]. The Gorkha possesses five distinct types of forest ecology according to altitudinal range; tropical, subtropical, temperate, sub-alpine, and alpine, which offer a wide array of vegetation, in which sub-tropical region is dominated with $P$. roxburghii and Schima-Castanopsis forests where this study was focused.

The study area falls within the Ludikhola sub-watershed area of Gorkha district, located at $27^{\circ} 55^{\prime}$ $02.85^{\prime \prime}-27^{\circ} 59^{\prime} 43.88^{\prime \prime} \mathrm{N}$ and $84^{\circ} 40^{\prime} 41.87^{\prime \prime}-84^{\circ} 33^{\prime} 23.13^{\prime \prime E}$; altitude ranges from 318 to $1714 \mathrm{~m}$ asl; and mean annual temperature is $23.1^{\circ} \mathrm{C}$ [22]. The study was carried out in Ludi Damgade Community. Forest (LDCF).

Figure 1. Maps showing study area [The figures in Nepal's map indicates the name of the provinces of the country].

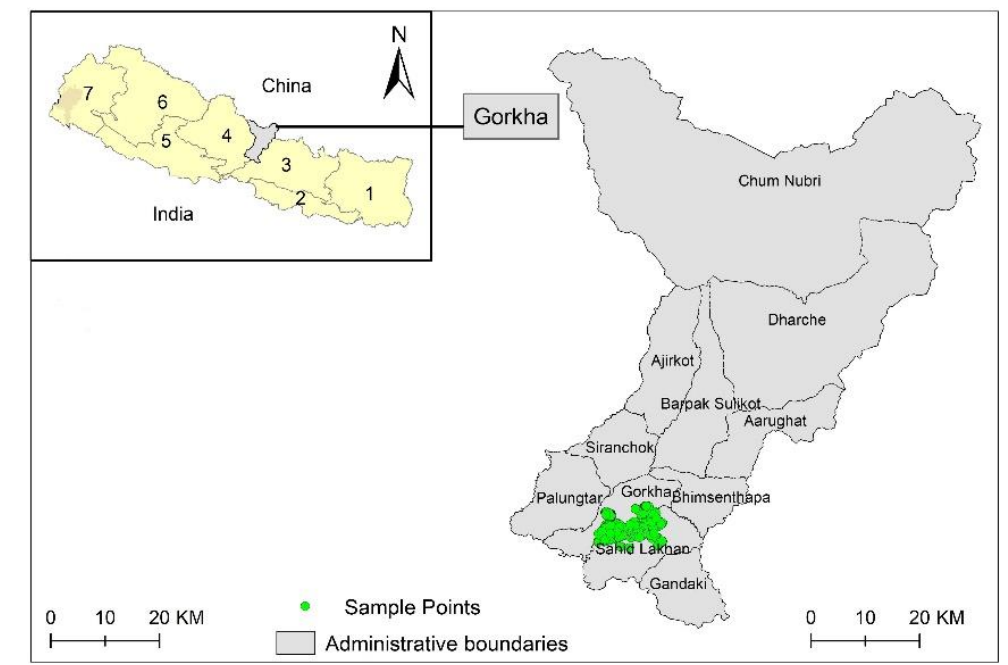

There was a 20 ha P. roxburghii stand between the broadleaved forests in Ludi Damgade community forest. This stand faced mostly towards the east, but also south-east and north-east in a few sample plots. The forest was in a gently sloping area with approximately two-thirds crown cover, and the soil was sticky clay soil and red-brown colour.

\subsection{Sample Design, Tree Coring and Age Determination}

Simple random sampling is employed to identify sample plots. As the study aim was to determine the age of $P$. roxburghii and examine temporal growth and forest's production. However, the research focuses on coring of $P$. roxburghii from the sample plots.

A Swedish Pressler's tree corer was used to core the P. roxburghii trees at breast height $(1.30 \mathrm{~m})$ from the ground) measured from the uphill side. The number of sample plots in the forests is - was determined based on already available Operational Plan data of Community Forests data based on stand's size variation. Altogether 63 trees were cored from the 20 sample plots. Along with coring, $\mathrm{DBH}$, total height, whorls counts and girth at the base $(15 \mathrm{~cm})$ were measured, and regeneration, ground cover, slope and aspect were accounted in every sample plot.

These cores were put into the straw of size bigger than the core size for safe handling and transportation. As soon as arrival at the laboratory from the field, these cores were fixed into a wooden frame and stretches along the frame in a array of row with tree code using sticky gums. The cores were smoothened with a wrapping paper until the distinct tree rings could be clearly visible by naked eye. The naked eyes, hand lens and microscope were used to count the number of rings that were supposed to develop in every year. The analysis was carried out at the Research Laboratory of the Central Department of Botany, Tribhuvan University, Kathmandu, Nepal. The basic assumption 
was that only a single ring would form in each year in P. roxburghii in Nepal's climate as explained by Jackson (1994) [1]. The total number of rings in a single core sample is the age of that sampled tree. The rate of tapering was estimated by using simple trigonometric and geometric relation from $\mathrm{GBH}$, $\mathrm{DBH}$ and their conversions.

\subsection{Above-ground Tree Biomass}

This study employed two allometric equations for biomass prediction from the same dataset. These two allometric equations were used because to make a comparison between different methods for biomass prediction in spite of employing the same dataset. The first one was the calculation of above-ground tree biomass (AGTB) using an allometric equation as suggested by Chave et al. (2005) (for the moist forest in which Gorkha district falls) [23].

Mathematically,

$$
A G T B=0.0509 \rho D^{2} H \ldots \text { Eq. (1) }
$$

where, $A G T B=$ above-ground tree biomass $(\mathrm{kg}) ; \rho=$ wood specific density $\left(\mathrm{kg}^{-1} \mathrm{~m}^{-3}\right) ; D=D B H=$ tree diameter at breast height $(\mathrm{cm})$; and $H=$ tree height $(\mathrm{m})$. The value of species specific wood density was ascertained from Department of Forest Research and Survey [3].

The next equation used for Above-ground tree biomass prediction was from the national allometric equation based on the following relation which was referenced from Forest Resource Assessment Report 2015 [3].

Mathematically,

$$
\begin{gathered}
A G T B=V^{*} \rho \ldots E q . \text { (2) } \\
V=\exp [a+b \operatorname{Ln}(D B H)+c \operatorname{Ln}(H)] \ldots \quad E q . \quad \text { (2.1) } \\
\operatorname{Ln}(V)=a+b \operatorname{Ln}(D B H)+c \operatorname{Ln}(H) \quad \ldots E q . \text { (2.2) }
\end{gathered}
$$

Where, $V$ is the total volume; $a$ is the intercept, $b$ is the coefficient for DBH and $c$ is the coefficient for height; and $\rho$ is the density of the wood. These values were obtained from forest carbon measurement directives published by the REDD Forestry and Climate Change Cell, Nepal [24]. For $P$. roxburghii, the value of $a, b, c$ is taken as $-2.977,1.9235,1.0019$ respectively; $\rho=650 \mathrm{~kg} \mathrm{~m}^{-3}$; $\mathrm{Ln}$ is natural $\log$ base value taken as 2.71828 .

To simplify the process for estimating below-ground biomass, the study used a root-to-shoot ratio value of 1:5 as prescribed by MacDicken, (1997) that the below-ground biomass is as $20 \%$ of the aboveground tree biomass [25].

\subsection{Statistical Tests}

The Student's $t$-distribution is applicable when the sampling distribution of sample means of variables is small. When the distribution of the sample means follows Student's $t$-distribution, the $t$ test can be applied to test the mean of every single sample. Regression analyses were performed as per necessity. In this study, the biomass and carbon stock of $P$. roxburghii has been estimated using regression analysis. All the statistical analysis and tests were performed using R [26] and Ms Excel.

\section{Results}

\subsection{Stand Structure and Age}

The major dimensions such as DBH, total height, biomass and age structure of the Pinus roxburghii stand were found to be approximately bell-shaped in the study area (Figure 2). The DBH classes ranged from 16-18 to $34-36 \mathrm{~cm}$ and the total height range was from 12 to $22 \mathrm{~m}$. Also, the biomass contained per tree ranged from $100 \mathrm{~kg}$ to $700 \mathrm{~kg}$ (Figure 2). 
Figure 2. Bar charts of the P. roxburghii stand structure in the study area. (1) DBH distribution; (2) Height distribution; (3) Biomass distribution as predicted by Eq. (1); and (4) tree age distribution.
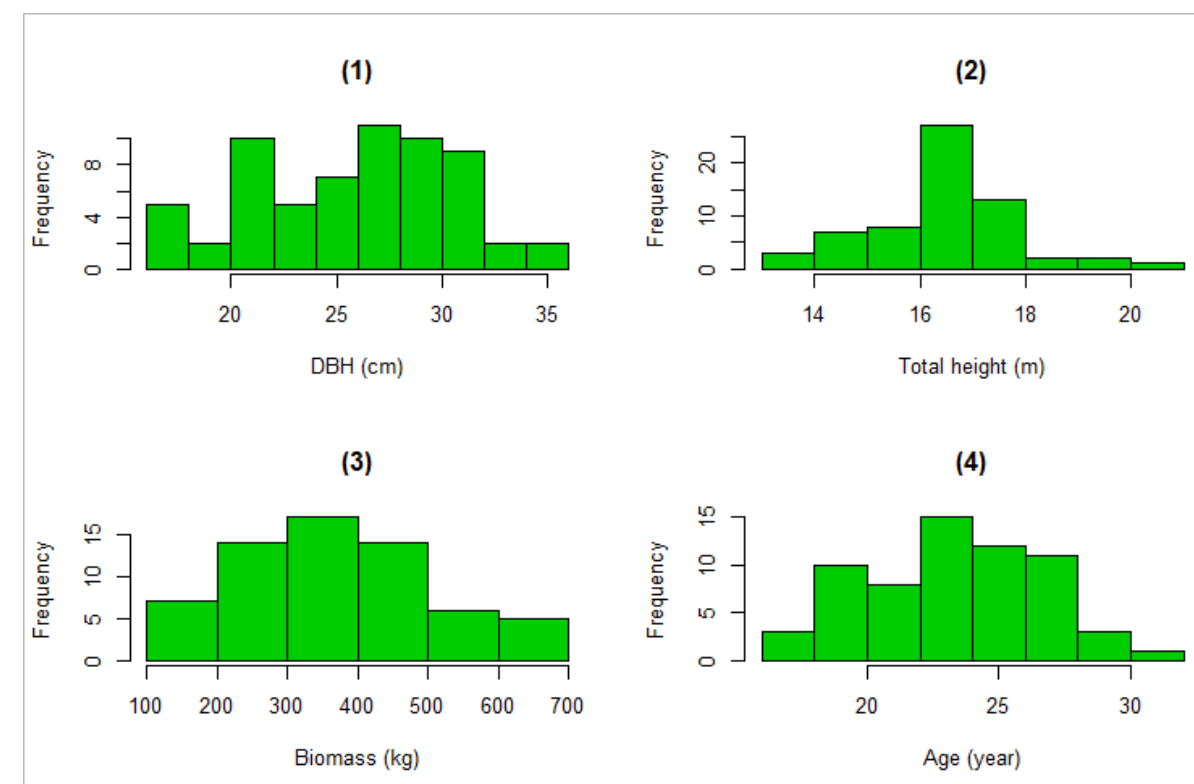

The $P$. roxburghii has a higher frequency in the middle-size classes $(20-25 \mathrm{~cm}$ and $25-30 \mathrm{~cm})$ with few trees on either size (Figure 2). This indicates a lack of age gradation from regeneration period to the rotation age of $P$. roxburghii in the study area. Rate of tapering of the stand was found to be $3 \mathrm{~cm}$ diameter decrease with height running at $100 \mathrm{~cm}$ from ground to upward of the trunk of $P$. roxburghii stand. The analysis showed that the $P$. roxburghii is about average of 24 years old (16 to 32 year ranges) that is known by assessment of cored samples. We investigated the P. roxburghii stand to find out the age of the trees with the reason to see the production of that age. The $P$. roxburghii area act as an experimental area for the study to find out the mean annual increment (MAI) that was $15 \mathrm{~kg}$ per trees per year biomass increment. The detail is in Table 1.

Table 1. A homogeneity $t$-test of different dimensions of P. roxburghii stand.

\begin{tabular}{cccc}
\hline Variables & Mean value & p-value & Significance \\
\hline DBH $(\mathrm{cm})$ & 25.78 & $<2.2 \mathrm{e}-16$ & Yes \\
\hline Height $(\mathrm{m})$ & 16.48 & $<2.2 \mathrm{e}-16$ & Yes \\
\hline Mean age $($ year $)$ & 23.97 & $<2.2 \mathrm{e}-16$ & Yes \\
\hline Biomass density estimated by Model 1 $\left(\mathrm{kg} \mathrm{tree}^{-1}\right)$ & 375.39 & 0.00027 & Yes \\
\hline Biomass density estimated by Model 2 $\left(\mathrm{t} \mathrm{ha}^{-1}\right)$ & 293.55 & & \\
\hline Basal girth at 30 cm height $(\mathrm{cm})$ & 91.82 & 0.00027 & Yes \\
\hline Girth at breast height $(\mathrm{cm})$ & 80.99 & $<2.2 \mathrm{e}-16$ & Yes \\
\hline Carbon density conversion from 1 Model $\left(\mathrm{t} \mathrm{ha}^{-1}\right)$ & 176.43 & 0.00027 & Yes \\
\hline Carbon density conversion from Model 2 $\left(\mathrm{t} \mathrm{ha}^{-1}\right)$ & 137.97 & $<2.2 \mathrm{e}-16$ & Yes \\
\hline
\end{tabular}

Single $t$-test of DBH of the $P$. roxburghii showed a very high degree of significant difference in DBH distribution, at the $5 \%$ significant level (Table 1$)$. The very low $p$-value $(\mathrm{p}<0.05)$ suggests a rejection of the null hypothesis in favour of the alternative hypothesis that the DBH of $P$. roxburghii tree is not homogenous (Table 1$)$. Similarly, the rest of all variables have significant $(p<0.05)$ different of the respective values from the study area (Table 1). This result indicates the significant variation on attributes of structure of $P$. roxburghii stand.

\subsection{Correlation Test}

The mean value, correlation coefficient, tested outputs with p-value and inference of the tests is presented in Table 2. 
Table 2. Correlation between pared variables of P. roxburghii using Karl Pearson's product-moment correlation test.

\begin{tabular}{cccc}
\hline Variables & Correlation coefficient (r) & p-value & Significance \\
\hline Age vs DBH & 0.68 & $1.2 \mathrm{e}-09$ & Yes \\
\hline Age vs Height & 0.08 & 0.534 & No \\
\hline Age vs Biomass (Eq. 1) & 0.65 & $7.58 \mathrm{e}-09$ & Yes \\
\hline Age vs Volume (Eq. 2.1) & 0.65 & $8.42 \mathrm{e}-09$ & Yes \\
\hline DBH vs Volume (Eq. 2.1) & 0.97 & $2.2 \mathrm{e}-16$ & Yes \\
\hline Height vs Volume (Eq. 2.1) & 0.36 & 0.003318 & Yes \\
\hline DBH vs Height & 0.14 & 0.279 & No \\
\hline DBH vs Biomass (Eq. 1) & 0.97 & $2.2 \mathrm{e}-16$ & Yes \\
\hline DBH vs Biomass (Eq. 2) & 0.97 & $2.2 \mathrm{e}-16$ & Yes \\
\hline Height vs Biomass (Eq. 1) & 0.36 & 0.0042 & Yes \\
\hline Height vs. Biomass (Eq. 2) & 0.36 & 0.0033 & Yes \\
\hline Basal girth vs GBH & 0.96 & $2.2 \mathrm{e}-16$ & Yes \\
\hline
\end{tabular}

The analysis shows that very high degree of positive correlation $(r=0.97)$ between DBH and biomass estimated by both equations (Eq. 1 and Eq. 2) were found. However, very weak positive correlation $(\mathrm{r}=0.08)$ between age and total height of $P$. roxburghii was obtained (Table 2). All pairs showed a significant $(\mathrm{p}<0.05)$ positive correlation coefficient $(\mathrm{r}=+)$ except between age-height and DBH-height of $P$. roxburghii (Table 2). The graphical presentation of relationships between age and other variables of $P$. roxburghii in the study area is presented in Figure 3. Meanwhile, the biomass and carbon predicted from Eq. 1 is used for graphical presentation throughout the paper, unless otherwise stated.

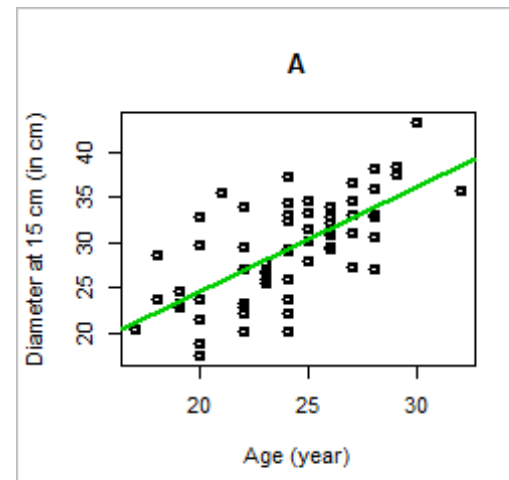

D

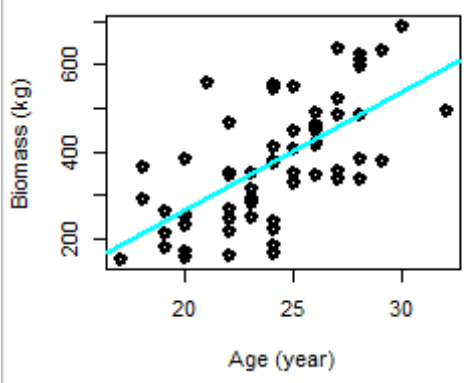

B

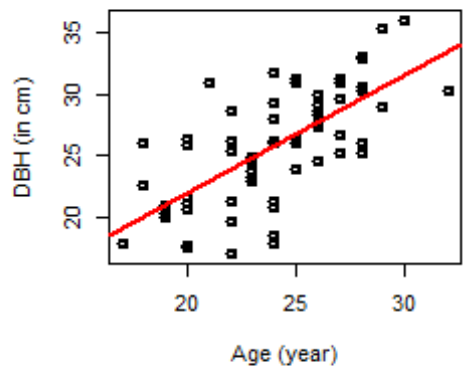

E

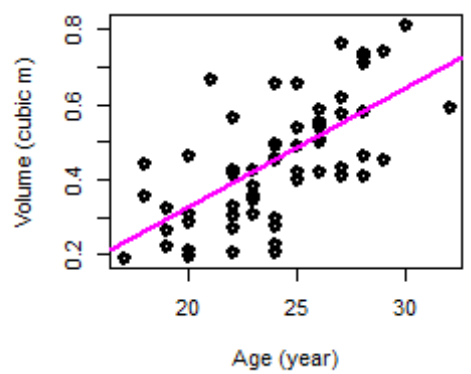

C

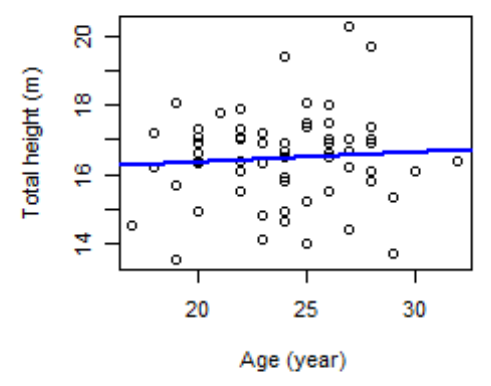

F

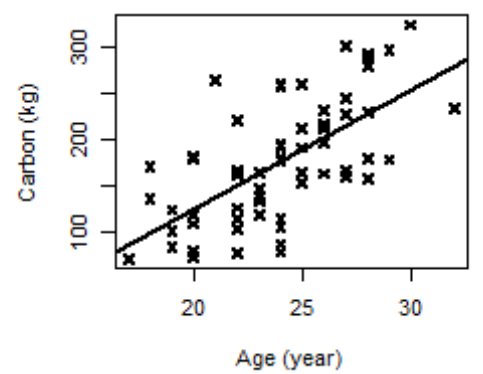

Figure 3. Relationship between various variables with the age of the P. roxburghii stands in the study area [A: The relationship between age and diameter at $15 \mathrm{~cm}$ height; $\mathrm{B}$ : The relationship between age and DBH; C: The relationship between total height and age; D: The relationship between age and biomass predicted by Eq. (1); E: The relationship between age and volume predicted by Eq. (2.1); and F: The relationship between age and carbon that is predicted by Eq.(1) and converted by the fracton of 0.47 of biomass]. 
Similarly, the relationships between random variables under study is presented in Figure 4 whose test outputs are already mentioned in Table 2.
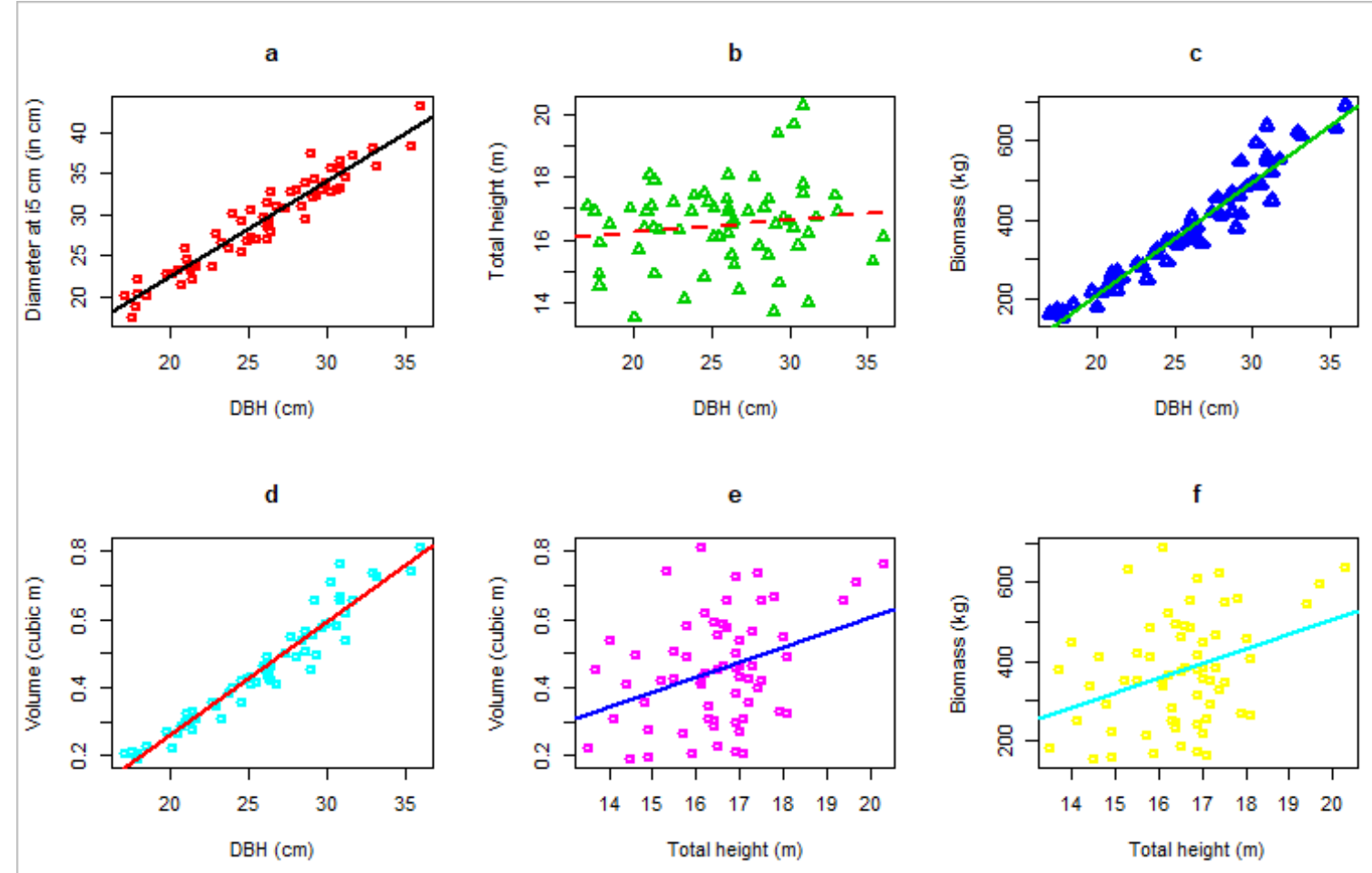

Figure 4. The graphical presentation and relationship between various variables of the P-roxburghii stand from the study area [a: The relationship between $\mathrm{DBH}$ and diameter at $15 \mathrm{~cm}$ height; b: The relationship between total height and $\mathrm{DBH}$; c: The relationship between $\mathrm{DBH}$ and biomass estimated by Eq. (1); d: The relationship between DBH and volume estimated by Eq. (2.1); e: The relationship between total height and volume predicted by Eq. (2.1); and f: The relationship between total height and biomass that is predicted by Eq.(1)].

All variable-pairs found a significant and positive correlation except total height to DBH and total height to volume of $\mathrm{P}$. roxburghii (Table 2). The corresponding significant relationships (Figure $4 \mathrm{a}, \mathrm{c}, \mathrm{d}, \mathrm{f}$ ) and non-significant relationship (Figure $4 \mathrm{~b}$ and e) are clearly indiced by the line graphs is the respective figures (Figure 4).

\section{Discussion}

The tree rings analysis is the valid source of information for various discipline that is further affirmed by our result too. Some of those tree rings assessment researches focus on climate changerelated information [27-30], drought signal and scenario analysis [29], disturbance history [31, 32]. However, we employed the tree ring for biomass production, carbon accumulation and potential enhancement of biomass in the P. roxburghii stand. This is a pioneer research for the country and for the site. Nonetheless, periodic biomass estimation gives some glimpse on biomass production and temporal enhancement but subsequent changes in methodologies on the analyses do not provide a good evidence for comparison and growth performance assessment [3]. Some site-specific studies are also available [33, 34], however, they provide point-based information on biomass (carbon) in the forest. Thus, this paper would be a reference for biomass production, carbon sequestration and rotation management of $P$. roxburghii forests for the site, in the country and beyond, in the long run for sustainable management of forests.

The age of forest stand would help to determine the rotation of the forest stand in addition to other significant environmental changes such as disturbance on forest or precipitation or drought [33]. Different types of false rings could be observed $[12,35]$ that they signify the major disturbances 
occurred in the environment. However, this study could not find such false rings in P. roxburghii and also verified with local aged people during the field visit that they did not experience such remarkable environmental adversities including prolonged drought or impactful frost in the study in their life memory.

The results show a roughly bell-shaped distribution of DBH, total tree height, biomass and age of the forest stand (Figure 2). This signifies the dominancy of pole-size stand structure of the forest. The structural analysis describes the forest's naturalness and complexity [35]. But, the unimodal structure of the forest is considered an unstable population as in this study. However, DBH distribution of all forests and Middle Mountain forests of Nepal is reversed J-shape indicating the continuous population structure $[3,19]$. This unimodal stand structure characterizes the more or less homogenous stand of the forest. This structure hinders sustainability in the long run due to the lack of regeneration and all-sized trees. Thus, intermediate silvicultural management intervention is required for intermittent material returns and economic benefits for forest-dependent and management communities (CF). In such case, intermediate thinning would be a silvicultural operation that helps to increase the ring width - high growth rate - more carbon sequestration, latewood proportion, and ring average density [7]. Due to the high correlation between DBH with other variables (Table 2, Figure 4), the unimodal distribution is characterized for biomass and carbon in the study area (Figure 2). Also, forest management needs to integrate maintenance of important structural components and patterns into timber production for biodiversity conservation and sustainable forestry [35].

The growth of height is not significantly correlated with the age of P. roxburghii (Table 3, Figure 3). Also, the correlation is not significant between height to $\mathrm{DBH}$, and height to biomass from the study area (Table 3, Figure 4). However, a significant correlation in the ratio of height to DBH is observed in western Pinus species [36], and some regression model explains up to $86 \%$ of the height to DBH ration for P. roxburghii in Nepal [37]. However, this study finds a non-significant but very weak positive correlation and insignificant linear regression between age and DBH with a total height of $P$. roxburghii. This may be due to height growth that culminates before the DBH gains climax in most of the forest species like $P$. roxburghii [16].

The tapering rate of $P$. roxburghii in the study area is estimated as $3 \mathrm{~cm}$ decrease in diameter from base to upward while running $100 \mathrm{~cm}$ of height of the trunk of tree and vice-versa. The tapering analysis is simply based on the trigonometric and geometric relationship. As suggested by Bontemps et al.- (2009), height is key for forest productivity analysis [38] similar to that of DBH growth and production assessment and prediction [16]. Remarkably, the analysis of the rate of tapering is pioneering work for Nepalese $P$. roxburghii. This will explore the opportunity for the future research area in diverse species, various ecological regions and physiographic zones. The result could guide for policy to practical implication of $P$ - roxburghii forest management. Analysis and inferences from so determined age of the forest stand in varied themes of application was not the scope of this study.

\section{Conclusions}

The $P$. roxburghii stand was found to be 24 years old. Stand age was found a key variable for $\mathrm{DBH}$, biomass and carbon enhancement; however, height is not highly correlated with age of $P$. roxburghii. The mean biomass is $375.39 \mathrm{~kg}^{-1} \mathrm{ree}^{-1}$ and mean biomass increment is $15 \mathrm{~kg}$ tree $^{-1}$ year-1. The rate of tapering found to be $3 \mathrm{~cm}$ diameter decreased with height running at $100 \mathrm{~cm}$ from the base to top of $P$. roxburghii stand that is height to DBH ration is 33.33:1 in the same unit. The potential carbon sequestration of $P$. roxburghii from the study area is expected to be unsustainable due to poor regeneration and unimodal stand structure in the long run. The nil regeneration, less density of trees, bell-shaped DBH distribution, absences of under-growth that interrupt the sustainable forest production due to lack of proper proportion of all-aged trees' composition in the forest stand, as a result, such forest diminished carbon sink potential like the $P$. roxburghii in the study area. This stand structure requires some management intervention for sustainable forest production.

\section{Patents}


Not applicable.

Supplementary Materials: The raw sampled data are presented in Table S1.

Author Contributions: The first author conceive, methodology designed, data collection, data analyzed, and original draft preparation. The second author involve in data editing, refining the sections, English checking, discussion writing. Both authors involved in review and editing the manuscript.

Funding: No funding applies to this research. No financial conflict of interest among authors in relation to this paper and data used.

Acknowledgments: The authors extend thanks to the Central Department of Botany, Tribhuvan University for providing the research platform, tools and equipment for data collection. Authors are thankful to Prakash Chandra Aryal, Faculty in Golden International College, Tribhuvan University, for his insightful comments and Dr Stephen Harrison, Associate Editor of Small-scale Forestry, for English proofing and thorough editing the manuscript.

Conflicts of Interest: The authors declare no conflict of interest

\section{References}

1. Jackson, J.K. Manual of Afforestation in Nepal: Volume 2; 2nd edition.; Department of Forest Research and Survey: Kathmandu, Nepal, 1994; Vol. 2;

2. MOFSC National Biodiversity and Action Plan of Nepal: 2014-2020 2014.

3. State of Nepal's forests; DFRS, Ed.; Department of Forest Research and Survey: Kathmandu, Nepal, 2015; ISBN 978-9937-8896-3-6.

4. Amatya, S.M.; Shrestha, K.R.; Cedamon, E. Nepal Forestry Handbook; Nepal Foresters' Association: Kathmandu, Nepal, 2016;

5. Aase, T.H. Are doomsday scenarios best seen as failed predictions or political detonators? The case of the 'Theory of Himalayan Environmental Degradation.' Geographical Journal of Nepal 2017, 10, 1-14, doi:10.3126/gjn.v10i0.17386.

6. MOFSC Resin Tapping Guidelines of Nepal; 2008;

7. Guller, B.; Isik, K.; Cetinay, S. Variations in the radial growth and wood density components in relation to cambial age in 30-year-old Pinus brutia Ten. at two test sites I SpringerLink Available online: https://link.springer.com/article/10.1007/s00468-011-0675-2 (accessed on Aug 29, 2020).

8. Gao, S.; Wang, X.; Wiemann, M.C.; Brashaw, B.K.; Ross, R.J.; Wang, L. A critical analysis of methods for rapid and nondestructivedetermination of wood density in standing trees. Annals of Forest Science 2017, $74,27$.

9. Gyawali, A.; Sharma, R.P.; Bhandari, S.K. Individual tree basal area growth models for Chir pine (Pinus roxberghii Sarg.) in western Nepal. Journal of Forest Science 2015, 61 (2015), 535-543, doi:10.17221/51/2015JFS.

10. Khan, M.S.; Khan, S.; Shah, W.; Hussain, M.; Shah, M. Height growth, diameter increment and age relationshipresponse tosustainable volumeof subtropical Chir pine (Pinusroxburghii)forest of KarakerBarikot forest. Pure Appl. Bio. 2016, 5, 560-567.

11. Aryal, P.C.; Dhamala, M.K.; Gaire, N.P.; Bhatta, S.; Suwal, M.K.; Bhuju, D.R.; Chhetri, P.K. Tree-ring climate response of two Larix species from the central Nepal Himalaya. Trop Ecol 2020, 61, 215-225, doi:10.1007/s42965-020-00082-w.

12. Speer, J.H.; Bräuning, A.; Zhang, Q.-B.; Pourtahmasi, K.; Gaire, N.P.; Dawadi, B.; Rana, P.; Dhakal, Y.R.; Acharya, R.H.; Adhikari, D.L.; et al. Pinus roxburghii stand dynamics at a heavily impacted site in Nepal: Research through an educational fieldweek. Dendrochronologia 2017, 41, 2-9, doi:10.1016/j.dendro.2016.01.005. 
13. Brancheriau, L.; Ghodrati, A.; Gallet, P.; Thaunay, P.; Lasaygues, P. Application of ultrasonic tomography to characterize the mechanical state of standing trees (Picea abies). J. Phys.: Conf. Ser. 2012, 353, 012007, doi:10.1088/1742-6596/353/1/012007.

14. Arciniegas, A.; Prieto, F.; Brancheriau, L.; Lasaygues, P. Literature review of acoustic and ultrasonic tomography in standing trees. Trees 2014, 28, 1559-1567, doi:10.1007/s00468-014-1062-6.

15. Brown, P.M.; Bhattacharyya, A.; Shah, S.K. Potential for Developing Fire Histories in Chir Pine (Pinus roxburghii) Forests in the Himalayan Foothills. trre 2011, 67, 57-62, doi:10.3959/2009-15.1.

16. Bontemps, J.-D.; Hervé, J.-C.; Dhôte, J.-F. Dominant radial and height growth reveal comparable historical variations for common beech in north-eastern France. Forest Ecology and Management 2010, 259, 1455-1463, doi:10.1016/j.foreco.2010.01.019.

17. Campbell, R.; McCarroll, D.; Robertson, I.; Loader, N.J.; Grudd, H.; Gunnarson, B. Blue Intensity In Pinus sylvestris Tree Rings: A Manual for A New Palaeoclimate Proxy. trre 2011, 67, 127-134, doi:10.3959/201013.1 .

18. Paudyal, K.; Baral, H.; Burkhard, B.; Bhandari, S.P.; Keenan, R.J. Participatory assessment and mapping of ecosystem services in a data-poor region: Case study of community-managed forests in central Nepal. Ecosystem Services 2015, 13, 81-92, doi:10.1016/j.ecoser.2015.01.007.

19. DFRS Middle Mountains Forests of Nepal. Forest Resource Assessment (FRA) Nepal, Department of Forest Research and Survey (DFRS). Kathmandu, Nepal. 2015.

20. Gaire, N.P.; Bhuju, D.R.; Koirala, M. DENDROCHRONOLOGICAL STUDIES IN NEPAL: CURRENT STATUS AND FUTURE PROSPECTS. FUUAST J BIOL 2013, 3, 1-9.

21. DOS Survey Department: Geographical location of the districts Available online: http://dos.gov.np/? (accessed on Aug 30, 2020).

22. DHM Department of Hydrology and Meteorology Available online: http://dhm.gov.np/meteorologicalstation/ (accessed on Jun 27, 2020).

23. Chave, J.; Andalo, C.; Brown, S.; Cairns, M.; Chambers, J.; Eamus, D. Tree allometry and improved estimation of carbon stock. Oecologia 2005, 87-99.

24. REDD Cell The forest carbon measurement guidelines 2011.

25. MacDicken, K. A Guide to Monitoring Carbon Storage in Forestry and Agroforestry Projects 1997.

26. R Core Team R: A language and environment for statistical computing. R Foundation for Statistical Computing, Vienna, Austria.; R Foundation for statistical Computing: Vienna, Austria, 2019;

27. Yang, J.; Cooper, D.J.; Li, Z.; Song, W.; Zhang, Y.; Zhao, B.; Han, S.; Wang, X. Differences in tree and shrub growth responses to climate change in a boreal forest in China. Dendrochronologia 2020, 63, 125744, doi:10.1016/j.dendro.2020.125744.

28. Tabakova, M.A.; Arzac, A.; Martínez, E.; Kirdyanov, A.V. Climatic factors controlling Pinus sylvestris radial growth along a transect of increasing continentality in southern Siberia. Dendrochronologia 2020, 62, 125709, doi:10.1016/j.dendro.2020.125709.

29. Altman, J. Tree-ring-based disturbance reconstruction in interdisciplinary research: Current state and future directions. Dendrochronologia 2020, 63, 125733, doi:10.1016/j.dendro.2020.125733.

30. Bhandari, S.; Speer, J.H.; Khan, A.; Ahmed, M. Drought signal in the tree rings of three conifer species from Northern Pakistan. Dendrochronologia 2020, 63, 125742, doi:10.1016/j.dendro.2020.125742.

31. Pandey, H.P.; Bhusal, M. A comparative study on carbon stock in Sal (Shorea robusta) forest in two different ecological regions of Nepal. Banko Janakari 2016, 26, 24-31, doi:10.3126/banko.v26i1.15498.

32. Pandey, H.P.; Pandey, P.; Pokhrel, S.; Mandal, R.A. Relationship between soil properties and forests carbon: 
Case of three community forests from Far Western Nepal. Banko Janakari 2019, 29, 43-52, doi:10.3126/banko.v29i1.25154.

33. Aryal, P.C.; Dhamala, M.K.; Gaire, N.P.; Bhatta, S.; Suwal, M.K.; Bhuju, D.R.; Chhetri, P.K. Tree-ring climate response of two Larix species from the central Nepal Himalaya. Trop Ecol 2020, 61, 215-225, doi:10.1007/s42965-020-00082-w.

34. Kidd, K.R.; Copenheaver, C.A.; Zink-Sharp, A. Frequency and factors of earlywood frost ring formation in jack pine (Pinus banksiana) across northern lower Michigan. Écoscience 2014, 21, 157-167, doi:10.2980/21-2-3708.

35. Põldveer, E.; Korjus, H.; Kiviste, A.; Kangur, A.; Paluots, T.; Laarmann, D. Assessment of spatial stand structure of hemiboreal conifer dominated forests according to different levels of naturalness. Ecological Indicators 2020, 110, 105944, doi:10.1016/j.ecolind.2019.105944.

36. Wonn, H.T.; O'Hara, K.L. Height:Diameter Ratios and Stability Relationships for Four Northern Rocky Mountain Tree Species. west j appl for 2001, 16, 87-94, doi:10.1093/wjaf/16.2.87.

37. Sharma, R.P. Modelling height-diameter relationship for Chir pine trees. Banko Janakari 2009, 19, 3-9, doi:10.3126/banko.v19i2.2978.

38. Bontemps, J.D.; Herve, J.C.; Dhote, J.F. Long-Term Changes in Forest Productivity: A Consistent Assessment in Even-Aged Stands. Forest Science 2009, 55, 549-564.

(C) 2020 by the authors. Submitted for possible open access publication under the terms and conditions of the Creative Commons Attribution (CC BY) license (http://creativecommons.org/licenses/by/4.0/). 